\title{
IIIISGUC.ORG
}

"İș, GÜC̣" ENDÜSTRi ilișKiLERI VE inSAN KAYNAKLARI DERGisi

"IS, GUC" INDUSTRIAL RELATIONS AND HUMAN RESOURCES JOURNAL

\section{Konaklama İşletmelerinde Algılanan Örgütsel Adaletin Yenilikçi Davranışa Etkisinde Kariyer Memnuniyetinin Aracılık Etkisi}

\author{
Mediation Effect Of The Career Satisfaction on The \\ Effect of The Perceived Organizational Justice on \\ Innovative Behavior in Accommodation Businesses
}

\author{
Dr. Mazlum ÇELIKK
}

Kara Harp Okulu, Savunma Bilimleri Enstitüsü

Nisan/April 2012, Cilt/Vol: 14, Say1/Num:2, Page: 99-122

ISSN: 1303-2860, DOI: 10.4026/1303-2860.2012.0201.x

Makalenin on-line kopyasına erişmek için:

http://www.isguc.org/? $\mathrm{p}=$ article\&id $=485 \&$ vol $=14 \&$ num $=2 \& y e a r=2012$

To reach the on-line copy of article:

http://www.isguc.org/?p=article\&id=485\&vol=14\&num=2\&year=2012

Makale İçin İletişim/Correspondence to: 
(c) 2000- 2012

“İşGüç” Endüstri İlişkileri ve İnsan Kaynakları Dergisi

"İşGüç" Industrial Relations and Human Resources Journal

\author{
Nisan/April 2012, Cilt/Vol: 14, Say1/Num: 2 \\ ISSN: 1303-2860, DOI: 10.4026/1303-2860.2012.0201.x
}

İş,Güç, Endüstri İlişkileri ve İnsan Kaynakları Dergisi, yılda dört kez yayınlanan hakemli, bilimsel elektronik dergidir. Çalışma hayatına ilişkin makalelere yer verilen derginin temel amacı, belirlenen alanda akademik gelişime ve paylaşıma katkıda bulunmaktadır.

İş, Güç, Endüstri İlişkileri ve İnsan Kaynakları Dergisi, 'Türkçe' ve 'İngilizce' olarak iki dilde makale yayınlanmaktadır. Dergi ulusal ve uluslar arası birçok indekste taranmaktadır. (CABELLS DIRECTORY, EBSCO SOCINDEX , INDEX ISLAMICUS, INDEX COPERNICUS, WORLDWIDE POLİTICAL SCIENCE ABSTRACTS, SOCIOLOGICAL ABSTRACT, ULAKBIM SOSYAL BİLIMLER VERİTANI, ASOS INDEX)

\section{Editör/Editor-in-Chief \\ Aşkın Keser (Uludağ University)}

Editör Yardimcıları/Co-Editors

K.Ahmet Sevimli (Uludağ University)

Gözde Yilmaz (Marmara University)

Uygulama/Design

Yusuf Budak (Kocaeli Universtiy)

\section{Tarandiğı Indeksler}

EBSCO SOCINDEX

Index ISLAMICUS

Index COPERNICUS

Worldwide Political Science

Abstracts

Sociological Abstract

ULAKBIM Sosyal Bilimler

Veritanı

CABELLS DIRECTORY

ASOS INDEX
Yayın Kurulu / Editorial Board

Dr. Erdem Cam (ÇASGEM)

Dr. Zerrin Firat (Uludağ University)

Doç. Dr. Aşkın Keser (Uludağ University)

Prof. Dr. Ahmet Selamoğlu (Kocaeli University)

Yrd. Doç. Dr. Ahmet Sevimli (Uludă̆ University)

Doç. Dr. Abdulkadir Șenkal (Kocaeli University)

Doç. Dr. Gözde Yilmaz (Marmara University)

Dr. Memet Zencirkıran (Uludă̆ University)

Uluslararası Danışma Kurulu / International Advisory Board Prof. Dr. Ronald Burke (York University - CA)

Assoc. Prof. Dr. Glenn Dawes (James Cook University - AU)

Prof. Dr. Jan Dul (Erasmus University - NL)

Prof. Dr. Alev Efendioğlu (University of San Francisco - USA)

Prof. Dr. Adrian Furnham (University College London - UK)

Prof. Dr. Alan Geare (University of Otago - NZ)

Prof. Dr. Ricky Griffin (TAMU-Texas A\&M University - USA)

Assoc. Prof. Dr. Diana Lipinskiene (Kaunos University - LT)

Prof. Dr. George Manning (Northern Kentucky University - USA)

Prof. Dr. William L. Murray (University of San Francisco - USA)

Prof. Dr. Mustafa Özbilgin (Brunel University - UK)

Assoc. Prof. Dr. Owen Stanley (James Cook University - AU)

Prof. Dr. Işık Urla Zeytinoğlu (McMaster University - CA)

Ulusal Danışma Kurulu / National Advisory Board

Prof. Dr. Yusuf Alper (Uludă̆ University)

Prof. Dr. Veysel Bozkurt (İstanbul University)

Prof. Dr. Toker Dereli (Işık University)

Prof. Dr. Nihat Erdoğmuş (Şehir University)

Doç. Dr. Mustafa Kurt (Yalova University)

Prof. Dr. Ahmet Makal (Ankara University)

Prof. Dr. Süleyman Özdemir (İstanbul University)

Prof. Dr. Ahmet Selamoğlu (Kocaeli University)

Prof. Dr. Nadir Suğur (Anadolu University)

Prof. Dr. Nursel Telman (Maltepe University)

Prof. Dr. Cavide Uyargil (İstanbul University)

Prof. Dr. Engin Yildirim (Constitutional Court of Turkey)

Doç. Dr. Arzu Wasti (Sabancı University)

Dergide yayınlanan yazılardaki görüşler ve bu konudaki sorumluluk yazarlarına aittir.

Yayınlanan eserlerde yer alan tüm içerik kaynak gösterilmeden kullanılamaz.

All the opinions written in articles are under responsibilities of the outhors.

The published contents in the articles cannot be used without being cited. 


\title{
Konaklama İşletmelerinde Algılanan Örgütsel Adaletin Yenilikçi Davranışa Etkisinde Kariyer Memnuniyetinin Aracılık Etkisi
}

\author{
Mediation Effect Of The Career Satisfaction on The Effect of The \\ Perceived Organizational Justice on Innovative Behavior in \\ Accommodation Businesses
}

\author{
Dr.Mazlum ÇELIK \\ Kara Harp Okulu, Savunma Bilimleri Enstitüsü
}

\begin{abstract}
Özet
İşletmelerin rekabet yarışında onlara önemli katkı sağlayan yenilikçi davranışların ortaya çıkmasında, çalışanların adalet algılarmin etkisinin belirlenmesi ve bu etkide kariyer memnuniyetlerinin aracilık rolünün ortaya konulması bu araştırmanın sorunsalıdır. Antalya kent merkezinde faaliyet gösteren küçük ölçekli konaklama işletmelerinde çalı̧̧an 260 kişiden anket yöntemiyle toplanan verilerle gerçekleştirilen araştırma sonucunda, çalışanların adalet alg̨larının hem yenilikçi davranışlar hem de kariyer memnuniyetleri üzerinde etkili olduğu belirlenmiştir. Yapılan hiyerarşik regrasyon analizleri sonucunda, kariyer memnuniyetinin dağıtım adaleti ile yenilikçi davranış arasında tam, diğer iki boyut (prosedür ve etkileşim) ile yenilikçi davranışlar arasında kısmi aracılık etkisinin olduğu tespit edilmiştir.
\end{abstract}

Anahtar Kelimeler: Algılanan Örgütsel Adalet(AÖA),Kariyer Memnuniyeti(KM),Yenilikçi Davranış (YD).

\begin{abstract}
Defining the effect of the justice perceptions of the employees on the innovative behaviors making important contributions in the competitive rivalry of the businesses and determining the mediating role of the career satisfaction in this effect constitutes the basic core of this study. As a result of the data obtained by questionnaire conducted on 260 employees working in small-sized accommodation businesses established in the city center of Antalya, Turkey, it is determined that the justice perception of the employees has an effect on both their innovative behaviors and career satisfactions. In addition, as a consequence of the conducted hierarchical regression analyses, it is defined that the career satisfaction has a full mediating effect between the distributive justice and innovative behavior, and a partial mediating effect between the other two dimensions (procedural and interactional) and the innovative behaviors.
\end{abstract}

Key words: Perceived Organizational Justice(POJ), Career Satisfaction(CS), Innovative Behavior(IB). 


\section{Giriş}

Günümüzde işletmeler çok ciddi rekabet baskısı altında faaliyet göstermektedirler. Özellikle hizmet sektöründe, hizmet alanların memnuniyetlerini değişik yollarla diğer insanlara ulaştırdığ 1 düşünülürse, rekabet şartları daha da ağırlaşmaktadır. Bugünün işletmelerinde ürünün çekiciliği tek başına işletmelerin ayakta kalmasına yetmemekte, bunun yaninda kalitesiyle birlikte emsalsiz olması da önem arz etmektedir(Bolwijn ve Kumpe,1990; Harrison-Walker, 2001). Bu nedenle, rekabet yarışında işletmeler arasında fark yaratan önemli unsur, diğer işletmeler tarafından kısa sürede ve kolayca taklit edilemeyecek yenilikçi uygulamalardır (Jansen ve diğ. 2006).

Schumpter (1934) tarafından yenilikçilik, yeni ürün veya hizmetlerin, yeni üretim metotlarının, yeni örgütsel yapıların, yeni pazarların ve tedarik kaynaklarının bulunması veya geliştirilmesi ve uygulanması olarak tanimlanmaktadir (Wang ve Ahmed, 2004). Yaratıc fikirlerin ortaya konulması ve bunların uygulamaya geçirilmesi çalışanların performanslarına bağlıdır. Araştırmacılar da, işletmeler için bu kadar önemli olan bu çalışan davranışının ortaya çıkması için uygun şartları belirleme gayreti içerisindedir.

Çalışanların yenilikçi davranışlar sergilemesinde örgütsel adalet algılarının etkili olduğu düşünülmektedir. Adalet algısı, her çalışan için biriciktir (Greenberg, 1987) ve çalışanların örgüte katkıları ve kazançlarını diğer çalışanlarla veya kendi beklentileri ile mukayesesi sonucu ortaya çıkmaktadır (Robbins, 1996). Çalışanların adalet algıları, sadece maddi kazançlarına ilişkin yaptıkları bir değerlendirme ile değil, aynı zamanda kendilerini de etkileyen kararların nasıl alındı ̆̆1 ve kendilerine nasıl muamele edildiği konusundaki düşünceleri ile de şekillenmektedir (Chang ve Dubinsky, 2005; Bies ve Moag 1986).

Çalışanların yenilikçi davranışlarını etkileyebileceği düşünülen diğer bir değişken de kariyer memnuniyetidir. Kariyer memnuniyeti, çalışanların çalıştıkları işletmede beklentilerinin karşılanıp karşılanmadığ konusundaki değerlendirmeleri sonucu ortaya çıkmaktadır (Heslin, 2005). Kariyer memnuniyeti yüksek olan çalışanların, daha gönülden çalışacakları ve işletmeleri için faydalı olacağını düşündükleri davranışları sergileyecekleri beklenmektedir (Nerkar ve diğ., 1996; Bateman ve Organ, 1983).

Bu araştırma, çalışan sayısı az olan ve Antalya kent merkezinde faaliyet gösteren küçük ölçekli (çalışan sayısı 10-49)(Arslan, 2003) şehir otellerinde yapılmıştır. Bu otellerin özelliği, çalışanları tamamının genellikle birbirlerinden haberdar olmaları ve her türlü problemde müşteriyle birebir karşı karşıya kalmalarıdır(Erdem, 2004). Çalışanların gösterecekleri yaratıcı fikirler ve yenilikçi uygulamalar müşteri memnuniyetini etkileyebilmektedir. Bu yüzden, söz konusu işletmelerde çalışanların yenilikçi davranış sergilemesinde adalet algılarının etkili olup olmadığ1 ve bu etkide çalışanların kariyer memnuniyetlerinin aracılık edip etmediği bu araştırmanın sorunsalı olarak belirlenmiştir. Özellikle kariyer memnuniyetinin aracılık rolüne ilişkin alanda araştırmaya rastlanmaması nedeniyle elde edilen bulguların hem araştırmacılara hem de uygulayıcılara fayda sağlayacağına inanılmaktadır.

\section{Teori ve Hipotezler}

\subsection{Algılanan Örgütsel Adalet}

İnsanlar nasil toplumsal hayatlarında kendilerine adil davranılmasinı bekliyorlarsa, işletmelerde de çalışanlar yöneticilerinden kendilerine adaletli davranmalarını beklemektedirler (Taylor, 2003). Bu beklenti çalışanların yöneticilerine ve işe karşı olan tutumlarını etkilediğinden her dönemde araştırmacıların da gündeminde olmuştur. Adaletin örgütler üzerindeki öneminin anlaşılmasından sonra; ilk başlarda örgütlerdeki adaleti anlayabilmek için sosyal adalet teorileri (Homans, 1961; Adams, 1965; Stouffer ve diğ., 1949) uygulanmıs, adalet bir- 
çok farklı disiplinden türetilen teoriler ile açıklanmaya çalışılmıştır. Fakat bu teoriler toplumdaki sosyal etkileşim konusunda genel bilgiyi içermelerinden dolayı örgütsel davranışları tam olarak açıklayamamış ve ayrıca bu konudaki araştırmaları da kısıtlamişlardır. Bu nedenle örgütteki işlevlerle daha ilişkili, örgütsel değişkenlere karşı daha fazla duyarlı, çalışma yerindeki adaletin rolünü açıklayan örgütsel adalet kavramı literatüre kazandırılmıştır (Greenberg, 1987).

Her ne kadar "adalet" kavraminın sözlüklerde geçen "hak ve hukuku gözetme, hak ve hukuku yerine getirme gayreti" anlamına yakın olsa da örgütsel adalet, bireyin örgüt uygulamalarında hak ve hukukun gözetilip gözetilmediği konusundaki algısıdir (Koys ve DeCotiis, 1991: 273). Bu haliyle örgütsel adalet, çalışanların yöneticilerin kendilerine olan davranışlarının ve uygulamalarının değerlenmesi sonucunda ortaya çıkan algılarıdır ve kişiden kişiye farklılık göstermektedir (Greenberg, 1987). Bu alanda yapılan çalışmaların önemli bir kısmı, çalışanların adalet algılarını etkileyen faktörler ile birlikte adalet veya adaletsizlik algıları durumunda çalışanların gösterdikleri reaksiyonları belirlemeye yöneliktir (Lim, 2002).

Örgütsel adalete ilişkin ilk çalışmalar Adams (1965)'ın Eşitlik teorisi ile başlamıştır. Bu teori; bireylerin kendilerine ait girdi ve çıktıları diğerleri ile karşılaştırdıklarını ve yaptıkları karşılaştırma neticesinde eşitsizlikleri giderecek şekilde davranışlar gösterdiklerini iddia etmektedir (Robbins, 1996). Thibaut ve Walker (1975), adalet kavramını farklı şekilde değerlendirerek, işletmelerde işlerin yapılması için izlenen sürecin de çalışanların adalet algılarını etkilediğini ileri sürmüştür. Bies ve Moag (1986) ise, kişiler arasındaki ilişkilerin bireylerin adalet algıs1nın değişmesine yol açabileceğini ifade ederek, kişiler arası adalet kavramını literatüre kazandırmıştır. Bu boyutta dürüstlük, samimiyet ve çıktı ile ilişkili olan bireye başka bir kişinin gösterdiği ilgi önemlidir.

Örgütsel adaletin boyutları konusunda araştırmacılar fikir birliği sağlayamamışlarsa da örgütsel adalet kavrami; Cropanzano ve arkadaşları (2007: 36) tarafından dağıtım adaleti, etkileşim adaleti ve prosedür adaleti olmak üzere üç farklı boyut olarak kavramsallaştırılmıştır. Dağıtım adaleti; çalışanların almış oldukları ödül/çıktıların dağıtımının adaletli olup olmadığı konusundaki algılarıdır (Homans, 1961). Dağıtım adaleti; genellikle Adams (1965) 'in "eşitlik teorisi" ile izah edilmektedir. Adams'a göre; insanlar çıktıların seviyesi ile ilgilenmekten çok çıktıların adil dağıtılıp dağıtılmadığ $\breve{1}_{1}$ ile ilgilenmektedirler. Çıktıların adil olup olmadığını anlamanın bir yöntemi ise; sağlanan katkı (eğitim, zeka, tecrübe, vs.) ile elde edilen ödülün oranını hesaplamak ve diğerleri ile karşılaştırmaktır (Colquitt ve diğ., 2001: 426). Yaptı̆̆ karşılaştırma neticesinde eşitsizlik algısına sahip olan bireylerde eşitliği sağlama yönünde bir gerginlik durumu oluşmakta, bu eşitsizliği yok etmek için çabayı azaltma, iş ilişkilerini değiştirme gibi farklı davranışlar gösterilebilmektedir (Beugre, 2002: 1093).

Prosedür adaleti, 1970'lerde Thibaut ve Walker (1978) tarafından yapılan ve insanların sadece çıktılar ile ilgili olmadıklarını, çıktıyı tanımlayan süreçlerle de ilgili olduklarını ortaya koyan çalışmalara dayanmaktadir (Chang ve Dubinsky, 2005: 40). Cropanzano ve Folger (1996: 72) tarafindan “odaklanma neye karar verildiğinden, kararın nasıl verildiğine değişmiştir" şeklinde belirterek prosedür adaleti boyutunun nasil ortaya çıktığı izah edilmeye çalışılmıştır. Folger ve Konovsky (1989: 126) ise prosedür adaletini, örgütteki karar verme prosedürlerinin adil olup olmadığına ilişkin değerlendirme olarak tanımlamaktadır.

Etkileşim adaletini ayrı bir boyut olarak değerlendirilmesi konusunda, araştırmacılar arasında görüş ayrılıkları bulunmasına rağmen, bazı araştırmacılar etkileşim adaletini üçüncü ve farklı bir boyut olarak değerlendirmişlerdir (Bies, 2001; Bies ve Moag, 1986; Cropanzano vd., 2001). Etkileşim adaleti kavramı, ilk olarak Bies ve Moag (1986) tarafından incelenmiştir. Bies ve Moag (1986) 
prosedür ve etkileşim adaletinin birbirlerinden farklı olduklarını, bireyler arası ilişkilerin adaletin algilanmasında etkili olduğunu ileri sürmüşlerdir. Etkileşim adaleti, örgütsel kararların ve işlemlerin uygulanması esnasında bireyler arası davranışlarla ilgili bireylerdeki algıya odaklanmaktadır. Saygı, dürüstlük, şeref, nezaket gibi adaleti sağlayacak olan taraftan adaleti alacak olanlara yöneltilen sosyal duyarlılık göstergesi olan farkl1 "insani" davranışları da kapsamaktadır (Bies, 2001; Bies ve Moag, 1986). Etkileşim adaletinin özellikleri; iletişimde güvenilir olmayı ve insanlara nazik, saygılı olmayı gerektirmektedir. Bunu sağlayan süreçler ise, çalışanların katkısı ile yeteri kadar ilgilenme, kişisel ön yargıyı bastırma, karar verme kriterlerini uygulama, zaman içerisinde geri besleme, adaletli karar gibi beş davranış biçimi ile tanımlanmaktadır. Bu davranış biçimleri çalışanların algılarını etkileme de, adaletin algılanmasında, kararların kabulünde, örgütlere karşı tutumların şekillenmesinde önemli bir rol oynamaktadir (Konovsky ve Croponzano,1991; Korsgaard ve di.̆., 1995).

Etkileşim adaleti; bireyler arası adalet ve bilgisel adaletten oluşan iki farklı boyuttan oluşmaktadır (Colquitt ve diğ., 2006). Bilgisel adalet, kararların nasıl alındığını açıklamayı ve bireylere ilgilerine göre yeterli bilgi vermeyi içermektedir (Greenberg, 1993). Bu boyut diğer boyutla yakından ilgilidir. Bireyler arası ilişki de önemli bir konuda bilginin paylaşılmasıdır. Bireyler arası adalet, bir örgüt içinde veya sosyal yapı içerisinde bireylerin sosyal etkileşimde bulunmasını ifade etmektedir.

\subsection{Kariyer Memnuniyeti}

Türk Dil Kurumu sözlüğünde kariyer; "Bir meslekte zaman ve çalışmayla elde edilen aşama, başarı ve uzmanlık" olarak tanımlanmaktadır. İnsan kaynakları yönetimi alanında da, sözlüklerdeki anlamına yakın olarak " kişilerin örgüt hiyerarşisi içerisinde ilerlemesi ve terfi etmesi" anlaminda kullanılmaktadır. Kariyer memnuniyeti ise; kişi- nin bulunduğu pozisyondan veya kariyer basamağından duyduğu hoşnutluk olarak tanımlanmaktadır (Heslin, 2005).

Kariyer memnuniyetini, kişinin beklentilerine dayandiran tanımlamalar da bulunmaktadır. Schein (1978)'e göre kişilerin bulundukları statü ile gelirleri konusundaki değerlemeleri kariyer memnuniyeti iken; Greenhaus ve arkadaşları (1990), kişinin iş ve ilerleme potansiyeli konusundaki değerlendirmelerini kariyer memnuniyeti olarak görmektedirler. Her iki tanımlamada da kişiler tarafından yapılan değerlendirmeler ne kadar olumlu olursa kariyer memnuniyeti artmakta, olumsuz olursa da memnuniyetsizlik ortaya çıkmaktadır.

Kariyer memnuniyetini etkileyen faktörlerin neler olduğu konusunda farklı görüşler olmasina rağmen, Greenhaus (1990) tarafından genel bir değerlendirme yapılmış ve mesleki başarı, genel mesleki hedefler, gelirle ilgili hedefler, mesleki gelişim ve yeni becerilerin kazanılmasının kariyer memnuniyeti üzerinde etkili olduğu ileri sürülmüştür. Lepnurm ve arkadaşları (2006), kariyer memnuniyetinin aile sorumluluklarından strese, sağlanan hizmetlerin kalitesinden ödüllendirmeye ve işin nasıl organize edildiğine kadar birçok faktörden etkilenebileceğini belirtmişlerdir. Bunların dışında, cinsiyet, bulunulan kariyer basamağı, kişilerin özellikleri, işin özellikleri, yöneticilerin tutumları, gelir seviyesi, eğitim seviyesi gibi bir çok faktörün kariyer memnuniyetini etkilediği düşünülmektedir (Boles ve diğ., 2003; Saltzstein ve diğ., 2001).

Kariyer memnuniyeti ile ilgili yapılan çalışmaların önemli bir kısmı Vroom'un beklenti teorisi ile kişi çevre uyumu teorisine dayanmaktadır. Beklenti teorisine göre, insanlar zevklerini artırma ve sıkıntılardan kaçınma arzusu içerisindedir (Lawler ve Suttle; 1973). Bu görüşe göre yaptığ 1 işten ve bulunduğu pozisyondan zevk alan çalışanlarda kariyer memnuniyeti yüksek olacaktır. Kiși çevre uyumu teorisi ise, çalışanların kültürleri, ihtiyaçları, tercihleri ve yetenekleri ile örgüt yapıları, kaynaklar, ödüller ve rol- 
lerin uyumuna dayanmaktadır (Dawis ve Lofquist, 1984). Çalışanlar çalıştıkları organizasyonda bu uyumu hissettiklerinde yüksek kariyer memnuniyeti duyacakları düşünülmektedir.

\subsection{Yenilikçi Davranış}

Dünya ölçeğinde rekabet eden, farklı sektörlerde faaliyet gösteren işletmeler için müşterilerinin ihtiyaçlarını en ucuza, en kısa sürede ve en kaliteli bir şekilde karşılayabilmek hayati önem arz etmektedir (Doğan ve diğ., 2003). Söz konusu işletmelerin en önemli özelliklerinden birisi de rakiplerine göre daha yenilikçi davranabilmeleridir (Cook, 1998). Yazında yenilikçilik kavramı, araştırmacılar (Thusman ve Nadler, 1986; Damanpour ve Evan,1984; Camison-Zornoza, ve di $\breve{g} ., 2004)$ tarafindan kavramın farklı özellikleri ön plana çıkarılarak değişik şekillerde tanımlanmış olsa da, yapılan tanimlamaların en kapsamlisı Schumpter (1934)'e aittir. Schumpter (1934) ‘e göre yenilikçilik, yeni ürün veya hizmetlerin, yeni üretim metotlarının, yeni örgütsel şekillerin, yeni pazarların ve yeni tedarik kaynaklarının bulunması veya geliştirilmesidir (Wang ve Ahmed, 2004).

İşletmelerin yenilikçi olabilmeleri, çalışanlarının yenilikçi davranışlar sergileyebilmelerine bağlıdır(Sanders ve diğ., 2010). Yenilikçi davranış, bir çalışanın bilinçli bir şekilde ürün veya hizmetler, üretim metotları, örgütlenme şekilleri, pazarlama ve tedarik kaynaklarına ait yeni fikirleri organizasyona uygulaması (West ve Farr, 1989) ve başkaları tarafından üretilen yeni fikirleri benimsemesi (Woodman ve diğ., 1993) olarak tanımlanmaktadır. Yenilikçi davranışa yakın anlamı olan (Oldham ve Cummings, 1996) yaratıcı davranış ise, sadece yeni fikirlerin üretilmesidir (Zhou, 2003).

İş yerindeki yenilikçilik, Kanter (1988)'e göre üç safhalı kompleks davranışlardan oluşmaktadır. Yenilikçi davranışın birinci safhasinda, birey problemin farkına varmakta ve bu problemle ilgili yeni çözüm önerileri ile ortaya çıkmaktadır. Bu safhada fikirlerin yeni veya adapte edilmiş olmasınin önemi yoktur. İkinci safhada, yenilik fikrini ortaya atan birey, bulduğu fikirleri ve çözüm önerilerini destekleyecek ve meşrulaştıracak örgüt içi ve örgüt dışı destekler aramaktadır. Üçüncü ve son safhada ise, yenilikçi davranış gösteren birey tarafından çözümün örgüt içinde uygulanıp, denenebilmesi için model veya prototip üretilerek fikir maddi bir hale getirilmektedir (Carmeli ve diğ., 2006).

\section{Algılanan Örgütsel Adaletin çalışanların yenilikçi Davranışları Üzerine Etkisinde Kariyer Memnuniyetinin Aracılık Rolü.}

\section{1. Örgütsel Adalet Algısı ve Yenilikçi Davranış}

Çalışanlarından yenilikçi davranışlar bekleyen işletmeler, onları yenilikçi davranmaya sevk edecek yol ve yöntemleri bulma ve uygulama gayreti içerisindedirler (Sanders ve diğ., 2010). Bu konuda bireyci yaklaşım, yapısalcı yaklaşım ve interaktif süreç yaklaşımı olmak üzere üç teorik yaklaşım bulunmaktadır (Slappendel, 1996). Bireyci bakış açısı, kişilerin yenilikçi davranışlarını yaş, cinsiyet, eğitim seviyesi, kişilik ve bilişsel stil gibi bireysel özellikler ile açılamaya çalışmaktadır (Scott ve Bruce, 1994). Yapısalcı yaklaşıma göre ise kişiler, organizasyon stratejisi, yapısı, sağladığı kaynaklar, yönetici tutumları ve ödüllendirme politikaları gibi örgütsel uygulamaların çalışanların yenilikçi davranmalarında etkili olduğunu ileri sürmektedir (Damanpour, 1991). Bu iki yaklaşımla yenilikçi davranışların sebepleri, kısmen kişisel özelliklerle kısmen de örgütsel özelliklerle açıklanmaktadır. Fakat davranışın gerekçeleri hakkında bütüncül bir açıklama yapılamamaktadır (Giddens, 1995). Üçüncü yaklaşım olan interaktif süreç yaklaşımı ise, kişisel değerlendirmeler ile örgütsel özellikler arasındaki etkileşimin çalışanların yenilikçi davranış sergilemelerinde etkili olabileceğini belirtmektedir (Slappendel, 1996; Van de ven, 1986).

Örgütsel adalet algısı, hem yapısal yakla- 
şım, hem de interaktif süreç yaklaşımı kapsamına girmektedir. Yani çalışanların bireysel özellikleri dişında onların performanslarını etkileyen önemli bir etken olarak görülmektedir. Bu yüzden işletmeler çalışanların performanslarını, işbirliğini, örgüte olan bağlılıklarını artırmak maksadıyla onların beklentileri doğrultusunda adaletli davranma gayreti içerisine girmektedirler (Greenberg, 1990). Çalışanlar, uygulamaları adil buldukları sürece karşılıklılık ilkesi gereği daha fazla bağl1lık, yüksek iș memnuniyeti ve rol ötesi davranışlar sergileyebilmektedirler (Colquitt, ve diğ., 2001). Chang ve arkadaşları (2011) tarafından öğretmenler üzerinde yapılan bir çalışmada, öğretmenlerin adalet algılarının takım uyumu ve yaratıcı davranışları pozitif ve anlamlı olarak etkilediği tespit edilmiştir.

Amabile (1983)'e göre, görev motivasyonu yüksek ve yaptıkları iş konusunda yetenekli çalışanlar, uygun iş süreçlerinin bulunduğu ortamlarda yenilikçi davranabilmektedir. Bu şartlar, çalışanlarda yenilikçilik için önemli olan içsel motivasyonu sağlamaktadır (Oldham ve Cummings, 1996). Ortaya çıkan yüksek seviyeli motivasyon, yenilikçi davranışları artırmakta (Mumford ve diğ., 2002), çalışanları rol ötesi davranışlar sergilemeye teşvik etmektedir. Yenilikçilik de, rol ötesi bir davranış olarak görülmektedir (Bateman ve Organ, 1983). Organ (1988)'a göre, çalışanların rol ötesi davranışları adalet algılarından etkilenmektedir. Erkutlu (2008) tarafindan 10 devlet üniversitesinde çalışan öğretim elemanları üzerinde yapılan araştırmada, adalet ve boyutları ile örgütsel vatandaşlık davranışı arasında pozitif ve anlamlı bir ilişki tespit edilmiştir.

Eşitlik teorisi dağıtım adaleti üzerinde durmaktadır (Colquitt ve diğ., 2001). Buna göre çalışanlar, kendi katkıları ile elde ettikleri sonuçları çalışma arkadaşları ile kıyaslamakta, sonucu kendisine göre adil bulurlarsa performanslarını artırmaktadır. Yenilikçilik de, bir performans olarak görüldüğüne göre (Calantone, ve diğ., 2002) ör- gütte ücret, ödül ve her türlü kaynağın dağıtımının adil bulunması, çalışanların yenilikçi davranışlarını olumlu yönde etkileyebilecektir (Ang ve diğ., 2003; Greenberg, 1986). Abbey ve Dickson (1983)' a göre de, organizasyon ödül sisteminin adil olması ve yenilikçi davranışlar konusunda sağlanan destek, çalışanların yenilikçi davranmaları üzerinde etkili olabilmektedir. Janssen (2001) tarafından yapılan çalışmada da, dağitım adaleti algısının yüksek olduğu durumlarda, çalışanların daha fazla yenilikçi davranış sergilediklerini belirlenmiștir. Yine yapılan bazı araştırmalarda, algılanan dağ1tım adaleti ile iş performansı ve pozitif iş tutumları arasında pozitif bir ilişki bulunduğu tespit edilmiştir (Mcfarlin ve Sweeney, 1992, Williams, 1999; Ang ve diğ., 2003).

Örgütün maddi anlamda sağladığı çıkarlar ile olumlu dağıtım adaleti algıları, çalışanları örgütsel amaçlara yöneltmede yetersiz kalabilmektedir (Jahangir ve diğ., 2006). Çalışanların prosedür adaleti konusundaki algılarını şekillendiren (Ryan ve Ployhart 2000) ödüllerin dağıtılmasına ilişkin süreçler de, iş motivasyonunun temini ve artırılması için önemli bir araçtır (Erez ve Earley 1993). Karar süreçlerini adil bulan çalışanlar, örgüte katkılarını artırma gayreti göstereceklerdir. Chao ve arkadaşları (2010) tarafından yapılan çalışmada, çalışanların gösterdikleri yenilikçi davranışların prosedür adaleti algilarından pozitif ve anlamlı olarak etkilendiği tespit edilmiştir. Bunun dışında prosedür adaleti ile iş performansı arasındaki ilişkiyi inceleyen bir çok araştırmanın bulgusu da, prosedür adaleti algılarının is performansını pozitif ve anlamlı etkilediği yönündedir (Williams, 1999; Ang ve diğ., 2003; Greenberg, 1986; Lindquist, 1995; McFarlin ve Sweeney, 1992; Byrne, 2005).

Ayrıca, yöneticilerin çalışanlara karşı tutumları, yenilikçi iş davranışlarının ve yaratıcılığın ortaya çıkmasında etkili olabilmektedir (Scott ve Bruce, 1994). Yöneticilerin saygılı, nazik ve dürüst davrandıkları çalışanların, olumlu etkileşim adaleti 
içerisinde olacakları ve daha fazla yenilikçi davranışlar sergileyecekleri düşünülmektedir (Chebat ve Slusarczyk, 2005; Barclay ve diğ., 2005). Chao ve arkadaşları (2010) tarafından yapılan araştırmanın sonuçları da, bu düşünceyi desteklemektedir. Arslantaş (2005) tarafından iletişim ve diş ticaret alanında uzmanlaşmış bir firmada yapılan araştırmada, etkileşim adaleti ile örgütsel vatandaşlık davranışı arasında pozitif ve anlamlı bir ilişki belirlenmiştir. Yenilikçi davranışların rol ötesi davranışlar olduğu düşünüldügüünde, Arslantaş (2005)'ın araştırma bulguları da etkileşim adaleti algısının yenilikçi davranışları pozitif yönde etkileyebileceği fikrini desteklemektedir.

Kuramsal çerçeve ve yapılan görgül araştırmalara dayanılarak çalışanların adalet algıları ile yenilikçi davranış arasındaki ilişkiye yönelik aşağıdaki hipotezler ortaya konulmuştur.

H1: Çalışanların prosedür adaleti algıları yenilikçi davranış üzerinde pozitif ve anlamlı olarak etkilidir.

H2: Çalışanların dağıtım adaleti algıları yenilikçi davranış üzerinde pozitif ve anlamlı olarak etkilidir.

H3: Çalışanların etkileşim adaleti algıları yenilikçi davranış üzerinde pozitif ve anlamlı olarak etkilidir.

\section{2. Örgütsel Adalet Algısı ve Kariyer mem- nuniyeti}

Çalışanların bulundukları kariyer basamaklarından memnun olmaları, görev motivasyonları için önemlidir(Lepnurm ve diğ., 2006). Kariyer memnuniyeti ise, kişinin bulunduğu kariyer basamağından beklentilerine bağlıdır(Shein, 1978). Bazıları yüksek gelir beklerken, bazıları yeteneklerini geliştirmek, bazıları da daha yüksek kariyer basamaklarına ulaşma firsatları veya daha huzurlu bir çalışma ortamı arzu etmektedir (Greenhaus, 1990; Lepnurm ve diğ., 2006). Ama çalışanların önemli bir kısmı öncelikle kendilerine adil davranılmasinı talep etmektedirler (Karcioğlu ve Türker, 2010).
Örgütte bazı hakların verilmesi, çalışanların terfi ettirilmeleri veya ödüllerin dağ́tılması ile kararların alınmasında izlenen süreçler, çalışanların adalet algılarını etkilemektedir (Kickul ve diğ., 2005). Olumlu adalet algısı içerisinde olan çalışanlar, örgütte ulaşmayı arzu ettikleri hedeflere ulaşabileceklerine inanmakta ve kariyer memnuniyetleri artmaktadır (Ornstein, ve diğ., 1989; Sullivan, ve diğ., 1998). Organizasyonda çalışanlar, sağladıkları katkıların karşılığını almak istemektedirler. Diğer çalışanlar ile kendi katkılarını ve elde ettiği ödülleri k1yaslayan bir çalışan, adaletsizlik algısı içerisine düşerse, işe, örgüte ve yöneticilerine karşı olan tutumlarını gözden geçirme ihtiyacı duymakta (Walster, ve diğ., 1973), dolayısıyla bulunduğu pozisyon ve çalıştığ 1 işletmeden duyduğu memnuniyet düşebilmektedir (Bakhshi ve diğ., 2009). Bunların dişında, özellikle Maslow'un ihtiyaçlar hiyerarşisinde dördüncü ve beşinci seviyedeki çalışanlar, kendilerine iyi muamele edilmesini, saygılı ve nazik davranılmasını, görevleri ile ilgili konularda bilgilendirilmeyi talep etmekte, farklı davranışları adaletsizlik olarak değerlendirmekte ve memnuniyet seviyeleri olumsuz etkilenebilmektedir (Taylor,2003). İş yerinde yaşanan stres ve çal1şanların stresle baş etme yetenekleri, sosyal aktivitelere katılım ve ödül dağıtımındaki adalet, çalışanların kariyer memnuniyetlerine katkı sağlamaktadır (Lepnurm ve diğ., 2006). Hekimlerin kariyerlerinden duydukları memnuniyeti maddi ödüllerden ziyade takdir, sayg1 ve işin içeriği etkilemektedir (Lepnurm ve diğ., 2006). Yapılan araştırmada Kanadalı doktorları için gelirin önemli olduğu fakat kariyer memnuniyetini pek fazla etkilemediği belirlenmiştir (Kuerer, ve diğ., 2007).

King ve arkadaşları (1995) tarafından yapılan araştırma sonuçları da, çalışanların maddi ve manevi yönden tatmin edilmesi ile kariyer memnuniyeti arasında pozitif ve anlamlı bir ilişki bulunduğu tespit edilmiştir.

Adalet algıları ile kariyer memnuniyeti arasındaki ilişkiyi inceleyen çok fazla araş- 
tırma olmamasına rağmen adalet algiları- iş memnuniyeti ilişkisini inceleyen çalışmalar vardır. Örneğin; Janssen (2001) tarafından yapılan araştırmada adil bir örgüt ikliminde çalışanların sadece kendi istekleri ile çalışmakla kalmadıkları, aynı zamanda iş memnuniyetlerinin de yüksek olduğu belirlenmiştir. Yine Tremblay ve arkadaşları (2000) tarafından yapılan çalışmada, . iş tatimi ve çalışılan organizasyondan duyulan memnuniyeti dağıtım adaletinin prosedür adaletinden daha fazla etkilediği belirlenmiştir. Dinç ve Ceylan (2008) tarafından bir kamu kuruluşunda yapılan araştırmada da, örgütsel adaletin üç boyutu ile çalışan memnuniyeti arasında pozitif ve anlamlı bir ilişki bulunduğu tespit edilmiştir.

Elamin ve Alomaim (2011) tarafından Suudi Arabistan'da yerli ve yabancı işçiler üzerinde yapılan çalışmada, üç adalet boyutunun da çalışanların iş memnuniyetlerini pozitif ve anlamlı olarak etkilediği belirlenmiştir. Her ne kadar McFarlin ve Sweeney (1992) iş memnuniyetinin en fazla dağıtım adaletinden etkilendiğini ifade etse de, bu çalışmada iş memnuniyetinin en fazla etkileşim adaletinden, en az ise dağıtım adaletinden etkilendiği görülmüştür. Bakhshi ve arkadaşları (2009) tarafından yapılan çalışmada ise, dağıtım adaleti algısının çalışanların iş memnuniyetleri ve örgütsel bağlılıklarını pozitif ve anlamlı olarak etkilediği tespit edilmiştir.

H4: Çalışanların prosedür adaleti algıları kariyer memnuniyetleri üzerinde pozitif ve anlamlı olarak etkilidir.

H5: Çalışanların dağıtım adaleti algıları kariyer memnuniyetleri üzerinde pozitif ve anlamlı olarak etkilidir.

H6: Çalışanların etkileşim adaleti algıları kariyer memnuniyetleri üzerinde pozitif ve anlamlı olarak etkilidir.

\subsection{Kariyer Menuniyeti-Yenilikçi Davranış}

Yenilikçi davranışlar, genellikle çalışanların rol ötesi davranışlarıdır (Bateman ve Organ, 1983; Organ, 1997). Çalışanlar, ken- dilerini huzurlu hissettikleri ve beklentileri karşılandığı sürece, yenilikçi davranışlar gibi birçok rol ötesi davranışı gönüllü olarak sergileyebilmektedirler (Bateman ve Organ, 1983). Kariyer memnuniyeti de çalışanların beklentilerinin karşılandığı ve arzulanan hedeflere ulaşılabileceği konusundaki inançları sonucu ortaya çıkmaktadır (Greenhaus, 1990). Bu yüzden bulundukları pozisyondan memnun olan çalışanlar yetenekleri ölçüsünde yenilikçi davranışlar sergileyebilmektedirler (Nerkar, ve di ğ., 1996). Kariyer memnuniyetinin çalışanların yenilikçi davranışları üzerine etkisini araștıran çalışmaya rastlanmamıștır. Fakat çalışanların iş memnuniyetlerinin yenilikçi davranışlar üzerine etkisini araştıran araştırmalar bulunmaktadır. Örneğin; Sanders ve arkadaşları (2010) tarafından yapılan çalışmada çalışanların iş memnuniyetleri ile yenlikçi davranışları arasinda pozitif ve anlamlı ilişki tespit edilmiştir. Yine Mohamed (2002) tarafindan yapılan çalışmada da, çalışanların iş memnuniyetlerinin yenilikçi davranışları artırdığı tespit edilmiştir.

Çalışanların adalet algılarının yenilikçi davranışlarını olumlu yönde etkilediği konusunda teorik ve görgül araştırmalar bulunmasına rağmen kariyer memnuniyetinin seviyesinin bu etkiye aracılık edip etmediği konusunda bir araştırmaya rastlanmamıştır. Fakat çalışanların adalet algılarının kariyer memnuniyetlerini pozitif yönde etkileyebileceği ve kariyer memnuniyeti yüksek olan çalışanların da daha fazla yenilikçi davranışlar sergileyebileceği düşünüldüğünde kariyer memnuniyetinin iki değişken arasındaki ilişkide aracılık etkisinin olup olmadığı araştırmaya değer bulunmuştur. $\mathrm{Bu}$ düşüncemizi destekleyen dolaylı araştırmalar da bulunmaktadır. Örneğin; Ladebo (2008) tarafından Nijerya'da tarım işçileri üzerinde yapılan araştırmada, lider desteğinin örgütsel vatandaşlık davranışı üzerine etkisinde iş memnuniyetinin aracılık etkisi olduğu tespit edilmiştir. Han ve Jekel (2011) tarafından sağlık sektöründe yapılan araştırmada da, iş memnuniyetinin lider üye etkileşiminin işten ayrılma niyeti üzerine 
etkisinde aracılık rolü bulunduğu belirlenmiştir.

Yukarıda belirtilen kuramsal bilgi ve görgül araştırmalar 1şığında araştırmada test edilmek üzere geliştirilen hipotezler aşağ1dadir.

H7: Kariyer memnuniyeti çalışanların yenilikçi davranışlarını pozitif ve anlamlı olarak etkiler.

H8: Prosedür adaleti algılarının çalışanların yenilikçi davranışları üzerine etkisinde kariyer memnuniyetinin aracilık etkisi vardir.

H9: Dağıtım adaleti algılarının çalıșanların yenilikçi davranışları üzerine etkisinde kariyer memnuniyetinin aracılık etkisi vardir.

H10: Etkileşim adaleti alg1larının çalıșanların yenilikçi davranışları üzerine etkisinde kariyer memnuniyetinin aracılık etkisi vardir.

\section{Araştırmanın Yöntemi}

Prosedür adaleti (PA), dağıtım adaleti (DA) ve etkileşim adaletinin (EA) yenilikçi davranış (YD) üzerine etkisini ve bu etkide kariyer memnuniyetinin (KM) aracilık rolünü belirlemeye yönelik olan bu araştırmada, öncelikle örneklem ve ölçeklere ilişkin bilgilere yer verilmiştir. Ardından örneklemlerden elde edilen veriler doğrultusunda oluşturulan modele ilişkin analizler yapılmıştır. Bu kapsamda öncelikle her bir değişkenin doğrulayıcı faktör analizi yapılmış ardından değişkenler arası korelâsyonlar tespit edilmiştir. Yapılan hiyerarşik regresyon analizi ile hipotezler ve aracilık etkileri test edilmiştir. Ardından aracılık testlerini test etmek üzere sobel testleri yapılmıştır. Tüm bu analizler sonucunda elde edilen bulgular, mevcut literatür ile karşılaştırılarak yönetici ve araştırmacılara önerilerde bulunulmuştur.

\subsection{Araştırmanın Örneklemi}

Araştırma evrenini Antalya şehir merke- zinde faaliyet gösteren şehir oteli niteliğindeki küçük konaklama işletmeleri çalışanları oluşturmaktadır. Bu örneklemde yaklaşık 1500 kişi çalışmaktadır. Ana kütleden \%95 güvenilirlik sınırları içerisinde \%5'lik bir hata payı dikkate alınarak örneklem büyüklügü 185 kişi olarak hesap edilmiştir (Sekaran, 1992:253). Bu kapsamda kümelere göre örnekleme yöntemiyle tesadüfî olarak seçilen 25 işletmeden toplam 500 kişiye anket uygulaması yapılması planlanmıştır. Gönderilen anketlerden 322'si geri dönmüş, 260'1 analiz yapmak için uygun bulunmuştur.

Araştırmaya katılanların \%48,1'i kadın $(n=125), \% 78,8$ 'i ü $(n=204$ evlidir. Çalışanların \% 10.2' si $(\mathrm{n}=26)$ ilköğretim, \%25,1 $(n=65)$ ortaöğretim, \%64,7 $(n=168)$ lise eğitim derecesine sahiptir. Örneklemin, \%15,3'ü $(n=39)$ 18-24 yaş, \%19'u $(n=49)$ 25-32 yaş, $\% 19^{\prime} u$ (n=49) 33-40 yaş ve \%46,7'si de $(n=121)$ de 41 ve yukarı yaşlar arasındadır. Çalışanların \%26,5'i (n=68) 3 yıldan az, $\% 51,4^{\prime}$ ü (n=133) 4-9 y1l arası, \%13,7'si ( $\left.n=35\right)$ $16-21$ yıl arası ve $\% 8,4^{\prime}$ ü de $(n=21)$ de 22 ve yukarı yıl iş deneyimine sahiptir.

\subsection{Araştırmanın Ölçekleri}

Prosedür adaleti (PA), dağıtım adaleti (DA) ve etkileşim adaletinin (EA) yenilikçi davranış(YD) üzerine etkisini ve bu etkide kariyer memnuniyetinin (KM) aracilik rolünü belirlemeye yönelik olan bu araştırmada kullanılan ölçeklere ilişkin bilgiler aşağıda verilmektedir. Araştırmada kullanılan ölçeklerin doğrulayıcı faktör analizi sonucunda ölçeklerin uyum iyiliği değerleri Tablo 1 ve 2'de sunulmuştur. Ölçeklerin Cronbach alfa güvenirlik katsayıları SPSS paket programı ile doğrulayıcı faktör analizleri ise Amos programı ile analiz edilmiştir.

Adalet Algısı Ölçeği: Çalışanların adalet algılarını ölçmek üzere Moorman (1991) tarafından geliştirilen ve Niehoff ve Moorman (1993) tarafından geçerleme çalışması yapılan üç boyutlu (prosedür adaleti, dağıtım adaleti, etkileşim adaleti) adalet ölçeği kullanılmıştır. Bu ölçekte sorular "Çalıştığım iş- 
letmede işle ilgili kararlar tarafsız olarak alınır ", "Çalıştığım işletmede işle ilgili karar verilmeden önce tüm çalışanların fikri alınır ","Çalışma saatlerimle ilgili düzenlemenin adil olduğu kanaatindeyim", "Ücret düzeyimin adil olduğunu düşünüyorum ", "İşimle ilgili bir karar alınırken üstüm bana karşı kibar ve düşünceli davranır " ve "İşimle ilgili bir karar alınırken üstüm bana saygı ve itibar gösterir " şeklindedir. Toplam 20 ifadeden oluşan bu ölçekte cevaplar 5'li likert ölçeği ile alınmıștır (1=Kesinlikle katılmıyorum, $5=$ Kesinlikle katıliyorum). Niehoff ve Moorman (1993) tarafından yapılan güvenilirlik analizleri sonucunda, Cronbach alfa güvenirlik katsayısının prosedür adaleti için .85 , dağ 1 tım adaleti için .91 ve etkileşim adaleti için .92 olarak tespit edilmiştir.

Ölçeğin Türkçe'ye çok sayıda çevirisi ve uyarlaması mevcuttur. Bu çalışmada Karaeminoğulları (2006) tarafından Türkçe'ye uyarlaması yapılan ölçek kullanılmıştır. Karaeminoğulları (2006) tarafından yapılan güvenilirlik analizleri sonucunda Cronbach alfa güvenirlik katsayısı prosedür adaleti için .92, dağıtım adaleti için .86 ve etkileşim adaleti için .97 olarak tespit edilmiştir.

Ölçeğin KMO analiz sonucu sırasiyla.87, .86 ve .92 ve Barlett testi anlamlı $(\mathrm{p}=.000)$ olarak tespit edilmiştir. Bu çalışmada ölçeğin yapı geçerliliğini test etmek maksadıyla yapılan doğrulayıcı faktör analizi sonucunda Tablo-1'de görüldüğü gibi birinci düzey ilişkili modelin uyum iyiliği değerlerinin uygun olduğu ve verilerin ölçeğin üç boyutlu yapısına uyum sağladığı tespit edilmiş ve faktör yüklerinin dağıtım adaleti için $.70-.87$, prosedürel adaleti için .59 ile .79 ve etkileşim adaleti için .75-.87 arasında olduğu görülmüştür. Yapılan güvenirlik analizi sonucunda üç boyutlu ölçeğin toplam Cronbach alfa güvenirlik katsay1s1 .92 ve boyutların ise ayrı ayrı güvenirlik katsayıları sırasıyla $.85, .90$ ve .94 olarak bulunmuştur.

Kariyer Memnuniyeti Ölçeği (KM): İșletmelerde çalışanların kariyer memnuniyeti düzeyini belirlemek üzere Greenhaus ve ar- kadaşları (1990) tarafından geliştirilen ve Hofmans ve arkadaşları (2008) tarafından da kullanılan 5 maddeli kariyer memnuniyeti ölçeği kullanılmıştır. Bu ölçekte sorular "Kariyerimde elde ettiğim başarılarımdan memnunum" ve "Maddi kazanımlarım düşünüldüğünde kariyerimdeki ilerlemelerden memnunum " şeklindedir. Ölçekte cevaplar 5'li likert ölçeği ile alınmıştır (1=Kesinlikle katılmiyorum, 5=Kesinlikle katılıyorum). Hofmans ve arkadaşları (2008) tarafından yapılan güvenilirlik analizleri sonucunda Cronbach alfa güvenirlik katsayısı .74 olarak tespit edilmiştir.

Ölçeğin Türkçe geçerlemesi tarafımızdan yapılarak kullanılmıştır. Ölçeğin ölçek geçerleme prosedürlerine uygun olarak İngilizce-Türkçe ve Türkçe-İngilizce çevirileri alanında yetkin araştırmacılarla yapılmış, pilot ve asıl örneklem üzerinde uygulanarak keşfedici faktör analizi ve doğrulayıcı faktör analizi yapılmıştır. Analiz sonucunda verilerin ölçeğin tek faktörlü yapısına uyum sağladığ1 belirlenmiştir. Devam edilen analiz neticesinde 5 maddeli ölçeğin faktör yüklerinin .80 ile .89 arasında olduğu tespit edilmiştir. Ölçeğin KMO analiz sonucu .88 ve Barlett testi anlamlı ( $\mathrm{p}=.000)$ olarak belirlenmiştir. Bu analizlerin ardından AMOS paket programı ile doğrulayıcı faktör analizi yapilmıştır. Faktör analizi sonucunda verilerin ölçeğin tek faktörlü yapısına uyum sağladığ 1 ve faktör yüklerinin .70 ile .88 arasında olduğu tespit edilmiştir. Ölçeğin uyum iyiliği değerleri diğer ölçeklerinki ile birlikte Tablo 2 'de sunulmuștur. Yapılan güvenirlik analizi sonucunda ölçeğin toplam sonucunda Cronbach alfa güvenirlik katsayısı .91 olarak bulunmuştur.

Yenilikçi Davranış Ölçeği: Çalışanların yenilikçi davranışa eğiliminin ölçülmesinde Scott ve Bruce (1994) tarafindan kullanılan ölçek kullanılmıştır. Altı sorudan oluşan ölçekte sorular "Yeni teknolojiler, süreçler, teknikler araştırım ve fikirler üretirim" ve "Yenilikçiyim" şeklindedir. Ölçeğin güvenirlik katsayısı .89 olarak tespit edilmiş ve cevaplar 5'li likert ölçeği ile alınmıştır (1=Ke- 
sinlikle katılmiyorum, 5=Kesinlikle katılıyorum). Türkçe'ye uyarlaması Akkoç ve arkadaşları (2011) tarafından yapılan ölçeğin Cronbach alfa güvenirlik katsayısı .86 olarak tespit edilmiştir.

Ölçeğin KMO analiz sonucu .82 ve Barlett testi anlamlı $(\mathrm{p}=.000)$ olarak tespit edilmiştir. $\mathrm{Bu}$ çalışmada ölçeğin yapı geçerliliğini test etmek maksadıyla doğrulayıcı faktör analizi yapılmıştır. Faktör analizi sonucunda verilerin ölçeğin tek faktörlü yapısına uyum sağladiğ 1 ve faktör yüklerinin .61 ile .80 arasında olduğu tespit edilmiştir. Ölçeğin uyum iyiliği değerleri diğer ölçeklerinki ile birlikte Tablo 2' de sunulmuştur. Yapılan güvenirlik analizi sonucunda ölçeğin toplam Cronbach alfa güvenirlik katsayısı .87 olarak bulunmuştur.

\subsection{Bulgular}

Araştırma sonucunda elde edilen verilere, SPSS ve Amos programinda analizler yapılmıştır. Bu kapsamda, ilk aşamada araştırmada kullanılan ölçeklerin doğrulayıcı faktör analizleri(DFA) yapılmıştır. DFA sonuçları Tablo 1 ve 2' de toplu halde sunulmuştur.

İkinci aşamada ise, katılımcıların algıladıkları dağıtım adaleti, prosedür adaleti ve etkileşim adaleti ile kariyer memnuniyeti ve yenilikçi davranışa ilişkin elde edilen verilerin ortalamaları, standart sapmaları ve aralarındaki korelasyonlara bakılmıştır. Bulgular, Tablo 3'de sunulmuştur. Analizin üçüncü aşamasında, Baron ve Kenny (1986) tarafından önerilen üç aşamalı hiyerarşik regresyon analizi ile aracılık etkisi araştırılmiştır.

\section{Tablo 1}

Algılanan Örgütsel Adalet Ölçeği Doğrulayıcı Faktör Analizi Sonuçları

\begin{tabular}{|c|c|c|c|c|c|c|c|c|c|}
\hline Değişkenler & $X^{2}$ & df & $\begin{array}{c}\text { CMIN/DF } \\
<5\end{array}$ & $\begin{array}{l}\text { GFI } \\
>.85\end{array}$ & $\begin{array}{c}\text { AGFI } \\
>.80\end{array}$ & $\begin{array}{r}\text { CFI } \\
>.90\end{array}$ & $\begin{array}{l}\text { NFI } \\
>.90\end{array}$ & $\begin{array}{r}\text { TLI } \\
>.90\end{array}$ & $\begin{array}{c}\text { RMSEA } \\
<.08\end{array}$ \\
\hline Bağlantısız model & $\begin{array}{c}872.22 \\
1\end{array}$ & 170 & 5.1 & .77 & .72 & .82 & .78 & .80 & .11 \\
\hline 1. Düzey & 498.8 & 167 & 2.9 & .85 & .81 & .92 & .90 & .90 & .08 \\
\hline 2. Düzey & 612.5 & 127 & 4.8 & 1.00 & 1.00 & 1.00 & 1.00 & 1.00 & .26 \\
\hline
\end{tabular}

Not: Uyum iyiliği değer aralıkları "kabul edilebilir " standartlara göre düzenlenmiştir.

\section{Tablo 2}

Doğrulayıcı Faktör Analizi Sonucunda Ölçeklerin Uyum İyiliği Değerleri

\begin{tabular}{|c|c|c|c|c|c|c|c|c|c|}
\hline Değişkenler & $X^{2}$ & df & $\begin{array}{c}\text { CMIN/DF } \\
<5 \\
\end{array}$ & $\begin{array}{r}\text { GFI } \\
>.85 \\
\end{array}$ & $\begin{array}{c}\text { AGFI } \\
>.80 \\
\end{array}$ & $\begin{array}{r}\text { CFI } \\
>.90 \\
\end{array}$ & $\begin{array}{r}\text { NFI } \\
>.90 \\
\end{array}$ & $\begin{array}{r}\text { TLI } \\
>.90 \\
\end{array}$ & $\begin{array}{c}\text { RMSEA } \\
<.08\end{array}$ \\
\hline 1. Prosedür adaleti(PA) & 26.2 & 9 & 2.9 & .97 & .93 & .97 & .96 & .95 & .08 \\
\hline 2. Dağıtım adaleti (DA) & 10.8 & 4 & 4.5 & .98 & .95 & .99 & .98 & .98 & .07 \\
\hline 3. Etkileşim Adaleti(EA) & 47.1 & 18 & 2.6 & .96 & .92 & .98 & .97 & .97 & .07 \\
\hline $\begin{array}{l}\text { 3. Kariyer } \\
\text { memnuniyeti(KM) }\end{array}$ & 11.5 & 4 & .2 .8 & .98 & .94 & .99 & .98 & .98 & .08 \\
\hline 4. Yenilikçi davranış (YD) & 24.2 & 7 & 3.4 & .97 & .92 & .97 & .97 & .95 & .08 \\
\hline
\end{tabular}

Not: Uyum iyiliği değer aralıkları “kabul edilebilir " standartlara göre düzenlenmiştir. 
Tablo 3

Verilere ilişkin Ortalama, Standart Sapma ve Korelâsyon Değerleri

\begin{tabular}{lccccccc}
\hline & Ort. & S.S. & $\mathbf{1}$ & $\mathbf{2}$ & $\mathbf{3}$ & $\mathbf{4}$ & $\mathbf{5}$ \\
\hline 1.YD & 3.77 & .73 & $\mathbf{( . 8 7 )}$ & & & & \\
2. KM & 3.74 & 1.03 & $.44^{* * *}$ & $\mathbf{( . 9 1 )}$ & & & \\
3. PA & 3.14 & .88 & $.35^{* * *}$ & $.55^{* * *}$ & $\mathbf{( . 8 5 )}$ & & \\
4. DA & 3.04 & .1 .13 & $.18^{* *}$ & $.41^{* * *}$ & $.50^{* * *}$ & $\mathbf{( . 9 0 )}$ & \\
5. EA & 3.60 & .98 & $.42^{* * *}$ & $.60^{* * *}$ & $.75^{* * *}$ & $.61^{* * *}$ & $\mathbf{( . 9 4 )}$ \\
\hline
\end{tabular}

${ }^{*} \mathrm{p}<.05{ }^{* *} \mathrm{p}<.01$

Tablo 3’de de görüldüğü gibi araștırmaya konu edilen tüm bağımlı ve bağımsız değişkenler arasında anlamlı ilişkiler bulunmaktadır. Bu nedenle, değişkenler arasında önemli etkiler öngörülebilmektedir.

Analiz kapsamında modelde çoklu doğrusal bağlantı sorunu olup olmadığını belirlemek maksadiyla, doğrudaşlığa (collinearity) da bakılmıştır. Elde edilen tolerans ve VIF değerleri bağımsız değişkenler arası çoklu bağlantı olmadığını doğrulayan sonuçlar vermiştir (Tolerans > $.2, \mathrm{VIF}<10$ ).

Prosedür adaleti(PA) dağıtım adaleti (DA) ve etkileşim adaletinin(EA) yenilikçi davranış(YD) üzerine etkisini ve bu etkide kariyer memnuniyetinin (KM) aracilik rolünü açıklamak amacıyla, Baron ve Kenny (1986) tarafından önerilen üç aşamalı regresyon analizi yapılmıştır. Bu yönteme göre, bağımsız değişkenin bağımlı değişken ve aracı değişken üzerinde bir etkisi olmalıdır. Aracı değişken bağımsız değişkenle birlikte regresyon analizine dâhil edildiğinde, bağımsız değişkenin bağımlı değişken üzerindeki regresyon katsayısı düşerken, aracı değişkenin de bağımlı değişken (YD) üzerinde anlamlı etkisi sürmelidir. Bu kapsamda KM düzeyinin aracılık rolünü belirlemek amaciyla, PA-KM, YD, DA-KM, YD ve EA-KM, YD arasındaki ilişkiler hiyerarşik regresyon analizleri aracılığı ile ince- lenmiş ve Sobel testleri yapılmıştır. Aracılık testine ilişkin bulgular Tablo 4,5 ve 6 'da verilmektedir.

Aracılık testi kapsamında ilk aşamada bağımsız değişken prosedür adaleti ile yenilikçi davranış arasındaki ilişkilere bakılmıştır (Tablo-4). Bu aşamanın ilk adımında, PA'nın YD'yi $(\beta=.35, p<.001)$ anlamlı olarak etkilediği görülmüştür. İkinci adımda PA'nın aracılığı araştırılan KM'e olan etkisi araştırılmıştır. Analiz sonucunda PA'nın KM'i anlamlı olarak etkilediği $(\beta=.54$, $\mathrm{p}<.001)$ tespit edilmiştir. Bu adımda arac1lığ1 araştırılan KM'ın YD' ye olan etkilerine de bakılarak rapor edilmiştir. KM YD'yi ( $\beta=$ .46, $\mathrm{p}<.001$ ) anlamlı olarak etkilemektedir. $\mathrm{Bu}$ aşamanın son adımında ise, PA ve arac1-

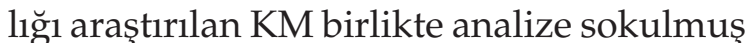
ve YD üzerindeki etkilerine bakılmıştır. Bu analiz sonucunda PA'nın KM ile birlikte analize sokulmasıyla YD' üzerindeki etkisi devam etmiş ve azalmış $(\beta=.15, p<.001)$, KM'in de YD üzerindeki etkisi devam etmiştir $(\beta=.37, \mathrm{p}<.01)$. Bu şartların sağlanmasının ardından aracilık etkisini teyit etmek maksadıyla Sobel testi yapılmış ve Sobel(z) anlamlı bulunmuştur ( $\mathrm{z}=6.6$, $\mathrm{p}<.001)$. Bu bulgu PA'nin YD'ye etkisinde KM'in kısmi aracılık rolü üstlendiğini göstermektedir. Bu bölüm analizleri sonucunda $\mathrm{H} 1, \mathrm{H} 4, \mathrm{H} 7$ ve aracilık hipotezi olan $\mathrm{H} 8$ ' in desteklendiği görülmektedir. 
Tablo 4

Aracılık Testi Sonuçları

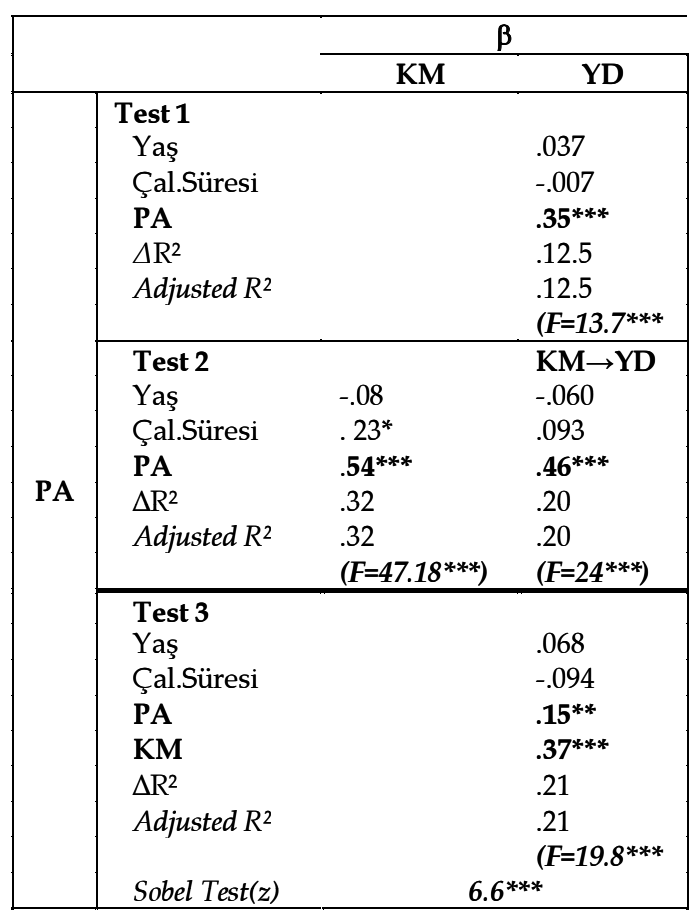

${ }^{* * *} \mathrm{p}<.001$

Dağıtım adaleti ile ilgili aracılık testinde dağıtım adaleti ile yenilikçi davranış arasındaki ilişkilere bakılmıştır (Tablo-5). Bu aşamanın ilk adımında, DA'nın YD'yi $(\beta=.18$, $\mathrm{p}<.001)$ anlamlı olarak etkilediği görülmüştür. İkinci adımda, DA'nın aracılığı araştırılan KM'e olan etkisi araştırılmıştır. Analiz sonucunda DA'nın KM'1 anlamlı olarak etkilediği $(\beta=.39, \mathrm{p}<.001)$ tespit edilmiştir. $\mathrm{Bu}$ aşamanın son adımında ise DA ve aracılığ 1 araştırılan KM birlikte analize sokulmuş ve YD üzerindeki etkilerine bakılmıştır. Bu analiz sonucunda DA'nın KM ile birlikte analize sokulmasıyla YD' üzerindeki etkisi ortadan kalkmış $(\beta=.005, p>05), K M^{\prime}$ in de YD üzerindeki etkisi devam etmiştir $(\beta=.45, \mathrm{p}<.001)$. $\mathrm{Bu}$ şartların sağlanmasının ardından aracılık etkisini teyid etmek maksadiyla Sobel testi yapılmış ve Sobel (z) anlamlı bulunmuştur $(\mathrm{z}=5.4, \mathrm{p}<.001)$. Bu bulgu da DA'nin YD'ye etkisinde KM'in tam aracılık rolü üstlendiğini göstermektedir. Bu bölüm analizleri sonucunda $\mathrm{H} 2$, $\mathrm{H} 5$ ve aracilık hipotezi olan $\mathrm{H} 9$ 'un desteklendiği görülmektedir.
Tablo 5

Aracılık Testi Sonuçları

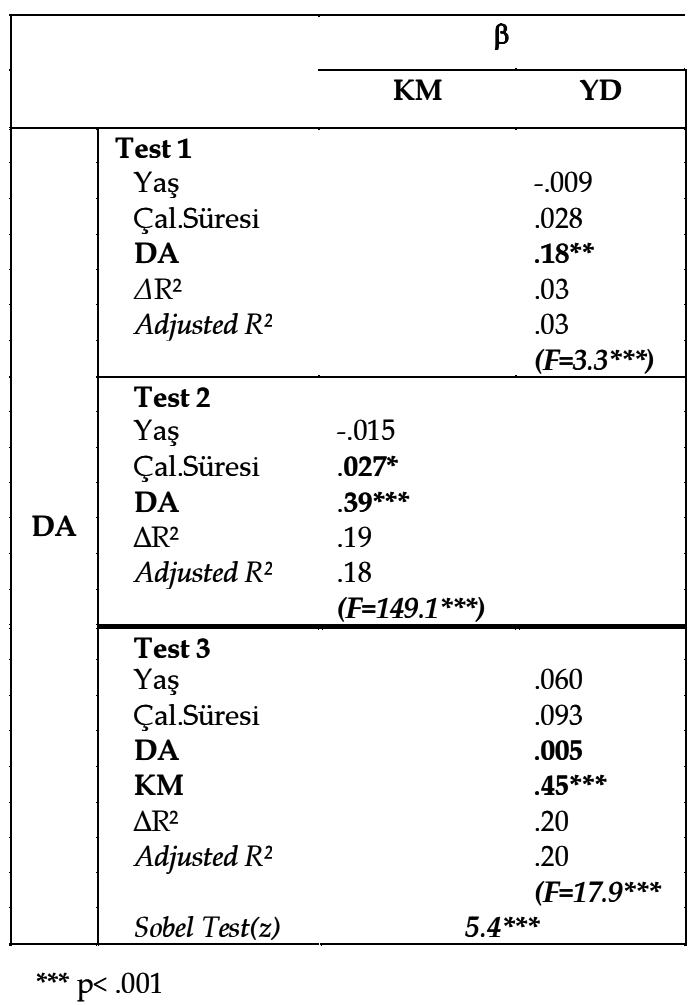

Etkileşim adaleti ile ilgili aracılık testinde etkileşim adaleti ile yenilikçi davranış arasındaki ilişkilere bakılmıştır(Tablo-6). Bu aşamanin ilk adıminda, EA'nin YD'yi $(\beta=.42, \mathrm{p}<.001)$ anlamlı olarak etkilediği görülmüştür. İkinci adımda, EA'nın aracılığ 1 araştırılan KM'e olan etkisi araştırılmıştır. Analiz sonucunda EA'nin KM'1 anlamlı olarak etkilediği $(\beta=.58, p<.001)$ tespit edilmiştir. $\mathrm{Bu}$ aşamanın son adımında ise, EA ve aracılığ1 araştırılan KM birlikte analize sokulmuş ve YD üzerindeki etkilerine bakılmıştır. Bu analiz sonucunda EA'nin KM ile birlikte analize sokulmasiyla $\mathrm{YD}^{\prime}$ üzerindeki etkisi devam etmiş ve azalmış ( $\beta=.23$, p>05), KM'in de YD üzerindeki etkisi devam etmiştir $(\beta=$ .32 , p<.001). Bu şartların sağlanmasının ardından aracılık etkisini teyid etmek maksadiyla, Sobel testi yapılmış ve Sobel (z) anlamlı bulunmuştur $(\mathrm{z}=6.9, \mathrm{p}<.001)$. Bu bulgu da EA'nin YD'ye etkisinde KM'in kısmi aracilık rolü üstlendiğini göstermektedir. Bu bölüm analizleri sonucunda H3, H6 ve aracilık hipotezi olan H10'un desteklendiği görülmektedir. 


\begin{tabular}{|c|c|c|c|}
\hline & \multicolumn{2}{|c|}{ Tablo 6} & çlar1 \\
\hline & & \multicolumn{2}{|r|}{$\beta$} \\
\hline & & KM & YD \\
\hline \multirow{3}{*}{ EA } & $\begin{array}{l}\text { Test } 1 \\
\text { Yaş } \\
\text { Çal.Süresi } \\
\text { EA } \\
\Delta \mathrm{R}^{2} \\
\text { Adjusted } R^{2}\end{array}$ & & $\begin{array}{l}.025 \\
-.020 \\
.42^{* *} \\
.16 \\
.17 \\
\left(F=20^{* * *}\right) \\
\end{array}$ \\
\hline & $\begin{array}{l}\text { Test } 2 \\
\text { Yaş } \\
\text { Çal.Süresi } \\
\text { EA } \\
\Delta \mathrm{R}^{2} \\
\text { Adjusted } \mathrm{R}^{2}\end{array}$ & $\begin{array}{l}-.011 \\
.022^{*} \\
.58^{* * *} \\
.37 \\
.37 \\
\left(F=58.3^{* * *}\right)\end{array}$ & \\
\hline & $\begin{array}{l}\text { Test } 3 \\
\text { Yaş } \\
\text { Çal.Süresi } \\
\text { EA } \\
\text { KM } \\
\Delta \mathrm{R}^{2} \\
\text { Adjusted } R^{2} \\
\text { Sobel Test }(z)\end{array}$ & & $\begin{array}{l}.059 \\
. .091 \\
.23^{* * *} \\
.32^{* * *} \\
.22 \\
.22 \\
\left(F=22.1^{* * *}\right) \\
6.9^{* * *}\end{array}$ \\
\hline
\end{tabular}

*** $\mathrm{p}<.001$

\section{Tartışma ve Sonuç}

Bu çalışma ile örgütsel adalet algısı boyutlarının çalışanların yenilikçi davranışları üzerindeki etkisi ve bu etkide kariyer memnuniyetinin aracılık edip etmediği araştırılmıştır. Araştırma, Antalya kent merkezinde faaliyet gösteren turistik olmayan şehir otellerinde çalışanlar üzerinde yapılmıştır. Sunulan hizmetin niteliği dişında rekabet yarışında çok fazla farklılığın yaratılamadı bu işletmelerde, çalışanların müşteri isteklerini karşılama konusunda geliştirdikleri yaratıcı fikirler ve yenilikçi uygulamaların ortaya çıkabilmesine yönelik önemli bulgular elde edilmiştir.

Beklendiği şekilde, çalışanların adalet algılarının üç boyutunun da yenilikçi davranışlar üzerinde pozitif ve anlamlı etkisinin olduğu, ancak etkileşim adaletinin diğer boyutlara göre yenilikçi davranışları daha fazla etkilediği görülmüştür. Elde edilen sonuçlar literatürle uyumludur (Slappendel, 1996; Van de ven, 1986; Chang ve diğ., 2011, Janssen, 2001; Chao ve diğ., 2010; Barclay ve diğ., 2005). Bu bulgular, araştırmaya konu olan işletmelerde kendilerine adil davranıldığını düşünen çalışanların, karşılıklılık ilkesi gereği işletmenin faydasına olabilecek yenilikçi davranışlar sergilediklerini göstermektedir (Organ, 1988).

Çalışanların adalet algılarının kariyer memnuniyetleri üzerinde de pozitif ve anlamlı etkisinin bulunduğu, ulaşılan bu sonucun literatürdeki diğer çalışmaların sonuçları ile uyumlu olduğu belirlenmiştir (Lepnurm ve diğ., 2006; Tremblay ve diğ., 2000; Elamin ve Alomaim, 2011). Çalışanların işletmeden beklentilerinin karşılanma derecesi kariyer memnuniyetlerini etkilediğinden (Greenhaus, 1990; Lepnurm ve diğ., 2006) kendilerine adil davranılmasının da çalışan açısından önemli bir beklenti olduğu sonucuna varılabilecektir (Karc1oğlu ve Türker, 2010; Taylor,2003).

Araştırmanın bulgularından bir tanesi de, kariyer memnuniyeti yüksek olan çalışanların daha fazla yenilikçi davranış sergileyeceklerine yöneliktir. Elde edilen bu sonuç literatürle de uyumludur (Nerkar, ve diğ., 1996; Mohamed, 2002). Bateman ve Organ (1983) tarafından ifade edildiği gibi kendisini mutlu ve huzurlu hisseden çal1şanlar rol ötesi davranışlar sergileyebilmektedir.

Örgütsel adalet algılarının çalışanların yenilikçi davranışları üzerine etkisinde kariyer memnuniyetinin aracılık rolüne ilişkin hipotezler araştırma bulgularıyla desteklenmiştir. Kariyer memnuniyetinin dağıtım adaleti ile yenilikçi davranışlar arasında tam aracılık, diğer adalet algısı boyutları ile yenilikçi davranış arasında ise kısmi aracilık etkisi yaptığ1 belirlenmiştir. Ulaşılan bu sonuç, olumlu adalet algıları nedeniyle yüksek kariyer memnuniyeti duyan çalışanların daha fazla yenilikçi davranışlar sergileyeceği dü- 
şüncesi ile uyuşmaktadır (Ladebo, 2008; Han ve Jekel 2011).

Sonuç olarak, yapılan regresyon analizleri ile örgütsel adalet boyutlarının (PA, DA, EA) çalışanların yenilikçi davranışları ve kariyer memnuniyetleri üzerinde pozitif ve anlamlı olarak etkili olduğu, kariyer memnuniyetinin yenilikçi davranışlar üzerinde pozitif ve anlaml etkisinin bulunduğu tespit edilmiştir. Bunların dışında, kariyer memnuniyetinin dağıtım adaleti ile yenilikçi davranışlar arasında tam aracılık, diğer adalet alg1sı boyutları ile yenilikçi davranış arasında ise kısmi aracılık etkisi yaptığ 1 belirlenmiştir.

Çalışan sayısı az olan şehir otellerinde yapılan bu araştırmanın sonuçları, çalışanların yenilikçi davranışları üzerinde hem adalet algılarınin hem de kariyer memnuniyetlerinin pozitif yönde etkili olduğunu göstermiştir. Bulunduğu kariyer basamağından memnun olan çalışanların ise, daha fazla yenilikçi davranacakları görülmüştür. Bu nedenle, çalışanların birbirleri ile sıkı ilişki içerisinde bulundukları küçük ölçekli işletmelerde, çalışanların yenilikçi davranışlarını geliştirmek ve artırmak için adalet algılarının kariyer memnuniyetlerini olumlu yönde etkileyecek şekilde değiştirilmesine ihtiyaç duyulmaktadır.

Bütün bunların yanı sıra, araştırmanın s1nırlılıkları da vardır. En büyük sınırlılığ tek bir sektörde ve sadece küçük ölçekli konaklama işletmelerinde yapılmasıdır. Farklı sektörlerde veya farklı ölçekteki işletmelerde yapılacak araştırmaların farklı sonuçlar verebileceği düşünülmektedir. Ayrıca araştırmada kullanilan verilerin, sadece Antalya bölgesinden birbirine yakın kültürel özellikler gösteren kişilerden toplanması da araştırmanın diğer bir kısıtıdır. Farklı kültürel özellikler taşıyan işgörenlerden toplanacak verilerin de önemli sonuçlar verebileceği değerlendirilmektedir.

Çalışanların yenilikçi davranışlarının ortaya çıkmasında etkili olabilecek öncüllerin belirlenmesi ve bu etkide kariyer memnuni- yetinin aracılık rolünün bulunup bulunmadiğının ortaya konulması nedeniyle bu araştırmanın örgütsel alan yazınına katkıları olabileceği değerlendirilmektedir. Müşterilerle çalışanların sıkı temas içerisinde oldukları ve yaratılan basit değişikliklerin müşteri memnuniyetine katkı sağladığ 1 turizm sektöründe, çalışanların yaratıcı düşünceler ortaya koyabilmeleri ve yenilikçi davranışlar sergileyebilmeleri için uygun şartların belirlenmesine yönelik daha farklı değişkenleri kapsayan araştırmalar yapılmasının uygulayıcılara ve araştırmacilara önemli faydalar sağlayabileceği düşünülmektedir. Ayrıca, adalet algılarının yenilikçi davranışlar üzerine etkisinde aracılık etkisi araştırılan kariyer memnuniyetinin düzenleyici rolüne ilişkin de çalışmalar yapılmasınin önemli sonuçlar verebileceği değerlendirilmektedir. 


\section{Kaynakça}

Abbey. A,. ve Dickson, J. W. (1983), R\&D Work Climate and Innovation in Semiconductors. Academy of Management lournal. 26, s.362-368.

Adams, J. S. (1965), Inequity in Social Exchange. In L. Berkowitz (Ed.), Advances in Experimental Social Psychology (Vol. 2, s. 267-299). New York: Academic Press.

Akkoç İ., Turunç Ö. ve Çalışkan A. (2011), Gelişim Kültürü Ve Lider Desteğinin Yenilikçi Davranış ve İş Performansına Etkisi: İş-Aile Çatışmasının Aracılık Rolü, "İş, Güç" Endüstri İlişkileri Ve İnsan Kaynakları Dergisi, 13:4, s. 83-114.

Amabile, T.M. (1983), The Social Psychology of Creativity: A Componential Conceptualization. Journal of Personality \& Social Psychology, 45, s.357-376.

Ang S., Dyne, L. V.ve Begley T. M., (2003), The Employment Relationships of Foreign Workers Versus Local Employees: A Field Study of Organizational Justice, Job Satisfaction, Performance and OCB, Journal of Organizational Behavior, 24, s.561-583.

Arslan, Ö., (2003), Küçük Ve Orta Ölçekli İşletmelerde Çalışma Sermayesi Ve Bazı Finansal Yönetim Uygulamaları, C.Ü. İktisadi ve İdari Bilimler Dergisi, 4:1, s. 121-135.

Arslantaş, C. C. (2005), Algılanan Adaletin Örgütsel Vatandaşlık Davranışı Üzerindeki Etkisini Belirlemeye Yönelik Görgül Bir Çalışma, Akademik Fener, Balıkesir Üniversitesi Bandırma İktisadi ve İdari Bilimler Fakültesi Dergisi, 2:4, s.205-218.
Bakhshi A., Kumar K., Rani E., (2009), Organizational Justice Perceptions as Predictor of Job Satisfaction and Organization Commitment, International Journal of Business and Management, 4:9, s. 145-154.

Barclay, L. J., Skarlicki, D. P., ve Pugh, S. D. (2005), Exploring the Role of Emotions in Injustice Perceptions and Retaliation", Journal of Applied Psychology, 90, s.629-643.

Baron, R. M. ve Kenny, D. A. (1986), The Moderator Mediator Variable Distinction in Social Psychological Research: Conceptual, Strategic, and Statistical Considerations. Journal of Personality and Social Psychology, 51, s.1173-1182.

Bateman, T. S. ve D. W. Organ (1983), Job Satisfaction and the Good Soldier: The Relationship Between Affect and Employee Citizenship, Academy of Management Journal, 26, s. 587-595.

Beugre, C. D. (2002), Understanding Organizational Justice and Its Impact on Managing Employees: An African Perspective, The International Journal of Human Resource Management, 13:7 s. 1091-1104.

Bies, R. J. (2001), International (in)Justice: The Sacred and the Profane. In J. Greenberg \& R. Cropanzano (Eds.), Advances in Organization Justice (s. 89-118). Palo Alto, CA: Stanford University Press.

Bies, R. J., ve Moag, J. F. (1986). Interactional Justice: Communication Criteria of Fairness. Research on Negotiations in Organizations, 1, s. 43-55. 
Boles, J. S., Wood, J. A. ve Johnson, J. (2003). Interrelationships of Role Conflict, Role Ambiguity, and Work-Family Conflict With Different Facets Of Job Satisfaction and the Moderating Effects of Gender. Journal of Personal Selling \& Sales Management, 23:2, s.99-113.

Bolwijn P. T. ve T. Kumpe (1990), Manufacturing in the 1990s-Productivity, Flexibility and Innovation," Long Range Planning, 23, s.44-7.

Byrne Z. S., (2005), Fairness Reduces the Negative Effects of Organizational Politics On Turnover Intentions, Citizenship Behavior and Job Performance, Journal of Business and Psychology, 20:2, s.175200.

Calantone, R.J., Cavusgil, T.S. ve Zhao, Y. (2002), Learning Orientation, Firm Innovation Capability, and Firm Performance. Industrial Marketing Management, 31:6, s. 515-524.

Camison-Zornoza, C., Lapiedra-Alcami, R., Segarra-Cipres, M. ve Boronat-Navarro, M. (2004), A Meta-Analysis Of Innovation and Organizational Size. Organization Studies, 25, s.331-61.

Carmeli, A., Meitar, R. ve Weisberg, J. (2006), Self-Leadership Skills and Abilities. International Journal of ManPower, 27, s.75-90.

Chang J.C., H.C. Hsiao, S.C. Chen, C.P. Chen, C.M. Chou ve C-H. Shen (2011), The Role of Perception of Effort-Reward in the Relationship Between Team Cohesion and Innovative Work Behaviour, 2nd WIETE Annual Conference on Engineering and Technology Education, Pattaya, Thailand, 25-28 January 2011

Chang, C-C. ve Dubinsky A. J. (2005), Organizational Justice in the Sales Force: A Literature Review With Propositions," Journal of Business-to-Business Marketing, 12:1, s.35-71.
Chao C-Y., Lin Y-S., Cheng Y-L. ve Tseng YC. (2010), Employee Innovation, Supervisory Leadership, Organizational Justice, And Organizational Culture in Taiwan's Manufacturing Industry, African Journal of Business Management , 5:6, S. 2501-2511.

Chebat, J. ve Slusarczyk, W. (2005), How Emotions Mediate The Effects of Perceived Injustice On Loyalty in Service Recover Situations: An Empirical Study", Journal of Business Research, 58, s.664-673.

Colquitt J. A., Scott B. A., Judge T. A. ve Shaw J. C. (2006), Justice and Personality: Using Integrative Theories to Derive Moderators of Justice Effects, Organizational Behavior and Human Decision Processes, 100, s.110-127.

Colquitt, J.A., Conlon, D.E., Wesson, M.J., Porter, C.O.L.H. ve Ng, K.Y.(2001), Justice at the Millennium - a Meta-analytic Review of the 25 Years of Organizational Justice Research. J. of Applied Psychology, June, s.425-445.

Cook, P. (1998), The Creativity Advantage Is Your Organization Leader Of The Pack. Industrial and commercial training. 30:5, s.179-184.

Cooper J.R. (1998), A Multidimensional Approach to the Adoption of Innovation'. Management Decision, 36:8, s.493502.

Cropanzano R., Bowen D.E. ve Gilliland S.W. (2007), The Management of Organizational Justice. Acad. Manage. Perspect. Nov., s. 34-48.

Cropanzano, R. ve Folger, R. (1996), Procedural Justice and Worker Motivation. In Steers, R.M., Porter, L.W. and Bigley, G.A. (Eds.), Motivation and Leadership at Work, s. $72-83$, New York: McGrawHill. 
Cropanzano, R., Byrne, Z. S., Bobocel, D. R. ve Rupp, D. E. (2001), Moral Virtues, Fairness Heuristics, Social Entities, And Other Denizens of Organizational Justice. Journal of Vocational Behavior, 58, s. 164-209.

Damanpour, F. (1991), Organizational Innovation: A Meta-analysis of Effects of Determinants and Moderators. Academy of Management Journal, 34:3, s.555-590.

Damanpour, F. ve Evan, W.M., (1984), Organisational Innovation and Performance: The Problem of "Organisational Lag". Administrative Science Quarterly, 29:3, s.392-409.

Dawis, R. W. ve Lofquist, L. H. (1984), A Psychological Theory of Work Adjustment, Minneapolis, MN: University of Minnesota Press.

Dinç, A., Ceylan A.,(2008), Kaçak Elektrik Kullanımıyla İlgili İdare Çalışanı Tutumunun Örgütsel Adalet ve İş Memnuniyeti İle İlişkisi, Çalışma Gruplarına Göre Farklılıklar. C.Ü. İktisadi ve İdari Bilimler Dergisi, 9: 2, s.13-29.

Doğan, Ö.İ., Marangoz M. ve Topoyan M. (2003), İşletmelerin İç ve Diş Pazarda Rekabet Gücünü Etkileyen Faktörler ve Bir Uygulama, Dokuz Eylül Üni. Sos. Bil. Ens. Dergisi, 5:2, s. 114-139.

Elamin A.M., Alomaim N., (2011), Does Organizational Justice Influence Job Satisfaction and Self-Perceived Performance in Saudi Arabia Work Environment?, International Management Review, 7:1, s. $38-49$.

Erdem B., (2004), Otel İşletmelerinde İnsan Kaynakları Planlamasinin Yeri ve Önemi, Balıkesir Üniversitesi Sosyal Bilimler Enstitüsü Dergisi, 7:11, s.35-54.

Erez, M. ve Earley, P.C. (1993), Culture, SelfIdentity, and Work, Oxford University Press, New York.
Erkutlu, H. (2008), Örgütsel Vatandaşlik Davranışları İle Örgütsel Adalet Kavramları Arasındaki İlişkide Örgüt Kültürünün Düzenleyici Rolü", 16. Ulusal Yönetim ve Organizasyon Kongresi Bildiriler Kitabı, İstanbul Kültür Üniversitesi, 16-18 May1s, s. 224-230.

Folger, R., ve Konovsky, M. A. (1989), Effects of Procedural and Distributive Justice on Reaction to Pay Raise Decisions. Academy of Management Journal, 32:1, s. $115-30$.

Giddens, A. (1995), The Constitution of Society. Cambridge, Polity Press.

Greenberg, J. (1987), A Taxonomy of Organizational Justice Theories, Academy of Management Review, 12:1, s. 9-22.

Greenberg, J. (1990), Organizational Justice: Yesterday, Today and Tomorrow, Journal of Management, 16: 2, s.399-432.

Greenberg, J. (1993), Stealing in the Name of Justice: Informational and Interpersonal Moderators of Theft Reactions to Underpayment Inequity. Organizational Behavior and Human Decision Processes, 54, s.81-103.

Greenhaus J. H., (1990), Effects of Race on Organisational Experiences, Job Performance Evaluations and Career Outcomes. Academy of Management Journal. $33: 1$, s. $64-86$

Greenhaus, J. H., Parasuraman, S., ve Wormley, W. M. (1990), Effects of Race On Organizational Experiences, Job Performance Evaluations, And Career Outcomes, Academy of Management Journal, 33, s.64-86.

Han (Helen) G. ve Jekel M. (2011), The Mediating Role Of Job Satisfaction Between Leader-Member Exchange and Turnover Intentions, Journal of Nursing Management, 19, s. 41-49 
Harrison-Walker, L. J. (2001), The Measurement of Word-of- Mouth Communication and an Investigation of Service Quality and Customer Commitment As Potential Antecedents, Journal of Service Research, 4, s.60-75.

Heslin, Peter A. (2005), Conceptualizing and Evaluating Career Success. Journal of Organisational Behaviour. 26, s. 113136.

Hofmans, J., Dries N. ve Pepermans, R.,(2008), The Career Satisfaction Scale: Response Bias Among Men and Women, Journal of Vocational Behavior, 73, s.397-403.

Homans, G. C. (1961), Social Behaviour: Its Elementary Forms. New York: Harcourt, Brace \& World, Inc.

Jahangır, N., Akbar M. ve Begum, N. (2006), The Role of Social Power, Procedural Justice, Organizational Commitment, and Job Satisfaction to Engerder Organizational Citizenship Behavior, ABAC Journal, 26(3), s. 21-36.

Jansen, J. J., Van Den Bosch F. A. ve Volberda H. W. (2006), Exploratory Innovation, Exploitative Innovation, and Performance: Effects Of Organizational Antecedents and Environmental Moderators", Management Science, 52:11, s. 1661-1674.

Janssen O, Van der Vliert E., West M.(2004), The Bright and Dark Sides of Individual and Group Innovation: A Special Issue Introduction. Journal of Organizational Behavior, 25, s. 129-45.

Janssen, O.(2001), Fairness Perceptions as a Moderator in the Curvilinear Relationships Between Job Demands, and Job Performance and Job Satisfaction. Academy of Management J., 44: 5, s.10391050
Kanter, R. (1988), When a Thousand Flowers Bloom: Structural, Collective and Social Conditions for Innovation at Work, In B.M. Staw \& L.L. Cummings (Eds.), Research in Organizational Behavior, 10, s.169-211, Greenwich, CT: JAI Press.

Karaeminoğulları, A. (2006), Öğretim Elemanlarının Örgütsel Adalet Algiları İle Sergiledikleri Üretkenliğe Aykırı Davranışlar Arasındaki İlişki ve Bir Araştırma, Yayımlanmamış Yüksek Lisans Tezi, İstanbul.

Karcıoğlu, F. ve Türker E.. (2010), Psikolojik Sözleşme İle Örgütsel Bağlılık İlişkisi: Sağlık Çalışanları Üzerine Bir Uygulama, Atatürk Üniversitesi İktisadi ve İdari Bilimler Dergisi, 24:2, s. 121-140.

Kickul, J., Gundry L. K. ve Posig M.,(2005), Does Trust Matter? The Relationship Between Equity Sensitivity and Perceived Organizational Justice, Journal of Business Ethics 56: s. 205-218.

King, L., Mattimore, L., King, D. ve Adams, G. (1995), Family Support Inventory for Workers: A New Measure of Perceived Social Support From Family Members, Journal of Organizational Behavior, 16:3, s. 235-259.

Konovsky, M.A. ve Cropanzano, R. (1991), Perceived Fairness of Employee Drug Testing as a Predictor of Employee Attitudes and Job Performance. Journal of Applied Psychology,76, s.698-707.

Korsgaard, M.A., Schweiger, D.M. ve Sapienza, H.J., (1995), Building Commitment, Attachment, and Trust in Strategic Decision-making Team: The Role of Procedural Justice, Academy of Management Journal, 38:1, s.60-84.

Koys D., DeCotiis T.A. (1991), Inductive Measures of Psychological Climate. Hum. Relat., 44:3, s. 265-285. 
Kuerer, H. M., Eberlein T. J., Pollock R. E., Huschka M., Baile W. F., Morrow M., Michelassi F., Singletary S. E., Novotny P., Sloan J. ve Shanafelt T. D. (2007), Career Satisfaction, Practice Patterns and Burnout among Surgical Oncologists: Report on the Quality of Life of Members of the Society of Surgical Oncology, Annals of Surgical Oncology 14:11, s.3043-3053.

Ladebo O. J. (2008), Perceived Supervisory Support and Organisational Citizenship Behaviours: Is Job Satisfaction a Mediator?, South African Journal of Psycho$\log y, 38: 3$, s. 479 - 488.

Lawler E. E. ve Suttlee J. L.(1973), Expectancy Theory and Job Behavior, Organizational Behavior And Human Performance, 9, s. 482-503.

Lepnurm R., Dobson R., Backman A., Keegan D. (2006), Factors Explaining Career Satisfaction Among Psychiatrists and Surgeons in Canada, Can J Psychiatry, 51:4, s. 243-255.

Lim Vivien K. G. (2002), The IT Way of Loafing on the Job: Cyberloafing, Neutralizing and Organizational Justice, Journal of Organizational Behavior J. Organiz. Behav. 23, s.675-694.

Lindquist, T. M. (1995), Fairness As an Antecedent to Participative Budgeting: Examining The Effects of Distributive Justice, Procedural Justice and Referent Cognitions On Satisfaction and Performance, Journal of Management Accounting Research, 7, s.122-147.

McFarlin, D. B. ve Sweeney, P. D. (1992), Distributive and Procedural Justice as Predictors of Satisfaction With Personal and Organizational Outcomes. Academy of Management Journal, 35:3, s.626-637.
Mohamed A. K. M.(2002). Assessing Determinant of Departmental Innovation. Personal Review, 31, s. 620-641.

Moorman, R.H. (1991), Relationship Between Organizational Justice and Organizational Citizenship Behaviors: Do Fairness Perceptions Influence Employee Citizenship?, Journal of Applied Psychology, 76, s.6.

Mumford, M.D., Scott, G.M., Gaddis, B. ve Strange, J.M. (2002), Leading Creative People: Orchestrating Expertise and Relationships. Leadership Quarterly, 13, s.705-50.

Nerkar., A. A, McGrath R. G. ve MacMillan I. C. (1996), Three Facets of Satisfaction and Their Influence on the Performance of Innovation Teams, Journal of Business Venturing, 11, s. 167-188,

Niehoff, R.T., Moorman, R.H, (1993), Justice As a Mediator of the Relationship Betweenmethods of Monitoring and Organizational Citizenship Behavior, Academy of Management Journal, 36:3, s.527-556.

OECD Oslo Manual(1997), Proposed Guidelines for Collecting and Interpreting Technological Innovation Data, TheMesaurement Of Scientific And Technological Activities, European Commission, Eurostat, Paris, http: / / www.oecd.org / dataoecd $/ 35 / 61 / 2367580 . p d f$

Oldham, G.R. ve Cummings, A. (1996), Employee Creativity: Personal and Contextual Factors at Work. Academy of Management Journal, 39, s.607-634.

Organ, D. W. (1988), Organizational Citizenship Behavior: The Good Soldier Syndrome. Lexington, MA: Lexington Books. 
Organ, D. W. (1997), Organizational citizenship Behaviour: It's Construct Clean-Up Time, Human Performance, 10, s. 85-97.

Ornstein, S., Cron, W. L., ve Slocum, J. W. (1989), Life Stages Versus Career Stage: A Comparative Test of he Theories of Levinson and Super. Journal of Organizational Behavior, 10, s.117-133.

Ryan, A. M., ve Ployhart, R. E. (2000), Applicants' Perceptions of Selection Procedures and Decisions: A Critical Review and Agenda for the Future. Journal of Management, 26, s. 565-606.

Sanders, K., Moorkamp M., Torka N., Groeneveld S. ve Groeneveld C. (2010), How to Support Innovative Behaviour? The Role of LMX and Satisfaction with HR Practices, Technology and Investment, 1, s. 59-68

Schein, E.H.(1978), Career Dynamics: Matching Individual and Organisational Needs. Reading, MA: Addison-Wesley in Heslin, Peter A. (2005) Conceptualizing and Evaluating Career Success. Journal of Organisational Behaviour. 26, s.113-136.

Scott, S. G., ve Bruce, R. A. (1994), Determinants of Innovative Behavior: A Path Model of Individual Innovation in The Workplace, Academy of Management Journal, 37:3, s. 580-607.

Sekaran, U. (1992), Research Methods for Business, Canada: John Wiley and Sons, Inc.

Slappendel, C. (1996), Perspectives on Innovation in Organisations. Organization Studies, 17:1, s. 107-129.

Stouffer, S., Lumsdaine A., Lumsdaine M., Williams R., vd. (1949), The American Soldier. Princeton, NJ: Princeton University Press.
Sullivan, S. E., Carden, W. A., ve Martin, D. F. (1998), Careers in the Next Millennium: A Reconceptualization of Traditional Career Theory. Human Resource Management Review, 8, s. 165-185.

Taylor A.J.W. (2003), Justice as a Basic Human Need, New Ideas in Psycho$\operatorname{logy} 21$, s. 209-219

Thibaut, J. ve L. Walker (1975), Procedural Justice: A Psychological Analysis, Hillsdale, NJ: Erlbaum.

Thibaut, J. ve L. Walker (1978), A Theory of Procedure, California Law Review, 66:3, s.541- 566.

Tremblay, M., B. Sire ve D. B. Balkin, (2000), The role of or-Ganizational Justice in Pay and Employee Benefit Satisfaction, and Its Effects on Work Attitudes, Group and Organization Management, 25, s.269-290.

Van de ven, A. (1986), Central Problems in the Management of Innovation. Management Science, 32:5, s.590-607.

Vroom V.H. (1960), Some Personality Determinants of the Effect of Participation. Englewood Cliffs, NJ: Prentice Hall.

Wang, C. L. ve Pervaiz K. A. (2004), The Development and Validation of the Organisational Innovativeness Construct Using Confirmatory Factor Analysis, European Journal of Innovation Management, 7:4, s.303-13.

West, M. A. ve Farr, J. L. (1989), Innovation at Work: Psychological Perspectives, Social Behavior, 4, s. 15-30.

Williams, S. (1999), The Effect of Distrıbutive and Prosedural Fustice On Performance, The Journal of Psychology, 133:2, s.183-193. 
Woodman R.W., Sawyer J.E. ve Griffin R.W. (1993). Toward a Theory of Organizational Creativity. Academy of Management Review, 18(2):293-321.

Zhou, J. (2003), When The Presence of Creative Coworkers is Related to Creativity: Role of Supervisor Close Monitoring, Developmental Feedback, and Creative Personality, Journal of Applied Psychology, 88 , s. 413-422. 